УДК 792.82(477)“195/199”

\author{
Майборода Назар Володимирович, \\ старший викладач кафедри хореографії \\ та сценічної пластики, \\ Київський національний університет \\ театру, кіно і телебачення імені \\ I. Карпенка-Карого \\ nazar.maiboroda@gmail.com \\ https://orcid.org/0000-0001-6962-7424
}

\title{
СПЕЦИФІКА КАСКАДЕРСЬКОГО МИСТЕЦТВА В СУЧАСНІЙ ВІТЧИЗНЯНІЙ КІНОІНДУСТРІЇ
}

\begin{abstract}
Мета статті - визначити особливості каскадерського мистецтва та специфіку постановки трюків на сучасних знімальних майданчиках в Україні. Методи дослідження. Застосовано аналітичний метод (для проведення мистецтвознавчого аналізу кінотрюків); структурно-функціональний (що посприяв розгляду процесу створення, постановки та зйомки трюків в єдності його структурних елементів); метод порівняльного аналізу каскадерської діяльності в сучасній кіноіндустрії та за радянських часів (з метою виявлення нових аспектів та характеристик постановки і виконання трюкових сцен відповідно до інтегрування сучасних технологій кінозйомки та етапу постпродакшн). Наукова новизна. Досліджено діяльність професійних організацій каскадерів України та провідних каскадерських груп (Міжнародної асоціації професійних каскадерів “Україна”, Ліги каскадерів України, Об’єднаної Ліги професійних кінних каскадерів "Stuntalot crew") початку XXI ст.; здійснено мистецтвознавчий аналіз постановки та виконання трюків у контексті розвитку сучасної вітчизняної кіноіндустрії; проаналізовано окремі аспекти роботи постановника трюкових сцен у фільмі, згідно специфіки жанру та ідейного задуму режисера. Висновки. Специфіка каскадерської діяльності в кіноіндустрії України зумовила доцільність використання започаткованого в радянському кінематографі другої половини XX ст. групового підходу - провідні каскадери та постановники трюків створюють власні групи, з якими працюють на знімальному майданчику.

Еволюція кінознімальної апаратури та залучення у кіноіндустрію комп’ютерної графіки на сучасному етапі значно сприяє каскадерській діяльності, ставши своєрідним поштовхом для розвитку. Не дивлячись на можливість створення найрізноманітніших спеціальних ефектів, каскадерське мистецтво в Україні лишається незамінною i невід'ємною частиною вітчизняної кіноіндустрії. Поєднання традиційних трюків та комп’ютерних технологій надає додаткові можливості для втілення режисерського задуму не перевищуючи бюджет фільму та посилення органічності екранного дійства.
\end{abstract}

Ключові слова: каскадерське мистецтво, кіноіндустрія, трюки, каскадер, постановки трюкових сцен.

Майборода Назар Володимирович, стариий преподаватель кафедры хореографии и сиенической пластики, Киевский наииональный университет театра, кино и телевидения имени И. Карпенка-Карого

Специфика каскадерского искусства в современной отечественной киноиндустрии

Цель статьи - определить особенности каскадёрского искусства и специфику постановки трюков на современных съемочных площадках в Украине. Методы исследования. Применен аналитический метод (для проведения искусствоведческого анализа кинотрюков); структурно-функциональный (что поспособствовал рассмотрения процесса создания, постановки и съемки трюков в единстве его структурных элементов); метод сравнительного анализа каскадерской деятельности в современной киноиндустрии и в советское время (с целью выявления новых аспектов и характеристик постановки и выполнения трюковых сцен в соответствии с интегрирования современных технологий киносъемки и этапа пост-продакшн). Научная новизна. Исследована деятельность профессиональных организаций каскадеров Украины и ведущих каскадерских групп (Международной ассоциации профессиональных каскадеров «Украина», Лиги каскадеров Украины, Объединенной Лиги профессиональных конных каскадеров, «Stuntalot crew») начала XXI в.; осуществлен искусствоведческий анализ постановки и выполнения трюков в контексте развития современной отечественной киноиндустрии; проанализированы отдельные аспекты работы постановщика трюковых сцен в фильме, согласно специфики жанра и идейного замысла режиссера. Выводы. Специфика каскадерской деятельности в киноиндустрии Украины обусловила целесообразность использования начатого в советском кинематографе второй половины XX в. группового подхода - ведущие каскадеры и постановщики трюков создают собственные групп, с которыми работают на съемочной площадке.

Эволюция киносъемочной аппаратуры и вовлечения в киноиндустрию компьютерной графики на современном этапе значительно способствует каскадерская деятельности, став своеобразным толчком для развития. Несмотря на возможность создания самых разнообразных спецэффектов, каскадерское искусство в Украине остается 
незаменимой и неотъемлемой частью отечественной киноиндустрии. Сочетание традиционных трюков и компьютерных технологий предоставляет дополнительные возможности для воплощения режиссерского замысла не превышая бюджет фильма и усилився органичность экранного действия.

Ключевые слова: каскадерское искусство, киноиндустрия, трюки, каскадер, постановки трюковых сцен.

Mayboroda Nazar, Senior Lecturer at the Chair of Choreography and stage plastic, Kiev National University theater,
cinema and television named after Karpenko-Kary

The specifics of stunt art in the modern local film industry

The purpose of the article is to determine the features of stunt art and the specifics of staging stunts on modern film sets in Ukraine. Methodology. The analytical method is applied (for carrying out an art historical analysis of movie stunts); structural and functional (which contributed to the consideration of the process of creating, staging and shooting tricks in the unity of its structural elements); a method of comparative analysis of stunt activities in the modern film industry and in Soviet times (to identify new aspects and characteristics of staging and performing stunt scenes following the integration of advanced film technology and the post-production stage). Scientific novelty. The activity of professional organizations of stuntmen of Ukraine and leading stunt groups (the International Association of Professional stuntmen "Ukraine," the League of stuntmen of Ukraine, the United League of professional stuntmen, "Stuntalot crew") was studied at the beginning of the XXI century; an art historical analysis of staging and performing stunts in the context of the development of the modern domestic film industry has been carried out; Some aspects of the work of the director of stunt scenes in the film are analyzed, according to the specifics of the genre and the ideological concept of the director. Conclusions. The specificity of stunt activities in the film industry of Ukraine made it expedient to use the second half of the 20th century, begun in Soviet cinema. A group approach - leading stuntman and stunt producers create their groups with which they work on the set. The evolution of filming equipment and the involvement of computer graphics in the film industry at the present stage significantly contributes to stunting activity, becoming a kind of the impetus for development. Despite the possibility of creating a wide variety of special effects, stunt art in Ukraine remains an indispensable and integral part of the domestic film industry. The combination of traditional tricks and computer technology provides additional opportunities for the realization of the director's intention without exceeding the budget of the film and increasing the organicity of the screen action.

Key words: stunt art, film industry, stunts, stunt performer, staging of stunt scenes.

Вступ. На початку XXI ст. інноваційні технічні зміни в кіноіндустрії беззаперечно вплинули на еволюціонування усіх видів кіномистецтва, зокрема каскадерського. Розвиток та інтегрування нових технічних засобів у кінематографію на усіх етапах циклічності фільму, від зйомок до демонстрації, найвідчутніше, з естетичних позицій, вплинуло на етап обробки зображення. Застосування комп'ютерних технологій дозволяє анімувати великі групи об'єктів, здійснювати анімацію тварин, моделювати «живих» акторів, використовувати комп'ютерну анімацію замість роботи дублерів та ін.

Новий період розвитку вітчизняного кінематографу, спираючись на досягнення комп’ютерних технологій, поступово змінює уявлення про каскадерську діяльність, відкриваючи перед постановниками трюкових сцен та виконавцями надзвичайні можливості. Це актуалізує дослідження проблематики каскадерської діяльності в контексті специфіки сучасної української кіноіндустрії з мистецтвознавчих позицій.

Аналіз досліджень. У вітчизняному науковому вимірі проблематика каскадерського мистецтва та його теоретичні основи наразі лишаються на стадії розробки. Одним із небагатьох сучасних науковців, предметом дослідження яких $є$ особливості розвитку каскадерської діяльності в XX ст. $є$ А. МасловЛисичкін. У наукових публікаціях «Каскадерські школи в радянському кінематографі» [3] та «Витоки й становлення каскадерського мистецтва» [2] дослідник систематизує існуючі теорії про витоки каскадерського мистецтва 3 часів видовищних ігор давніх часів, подає цікавий матеріал про розвиток каскадерства у німих фільмах та його становлення в сучасному кінематографі. Окремі аспекти постановки трюкових сцен в сучасній кіноіндустрії аналізує М. Теракопян у науковій праці «Розвиток кіно образності під впливом комп'ютерних технологій» [7] та ін. Проте у вітчизняному науковому полі й досі відсутні грунтовні праці, присвячені історії та теорії професійного каскадерського мистецтва у контексті розвитку світової кіноіндустрії, в яких було б зібрано та впорядковано фактологічний матеріал виконання та постановки трюкових сцен на вітчизняних та зарубіжних знімальних майданчиках.

Мета статті - визначити особливості каскадерського мистецтва та специфіку постановки трюків на сучасних знімальних майданчиках в Україні.

Виклад основного матеріалу. Кінотрюк - це складна фізична дія, яка є небезпечною для здоров'я людини і виконується у потрібний час у потрібному місці за командою режисера [5]. На відміну від циркового трюку, кінотрюк має власну специфіку - по-перше, він виконується в нестандартних умовах, а по-друге, нерідко з обмеженою кількістю репетицій.

Відповідно до загальновизнаної класифікації розрізняють висотно-акробатичні (поділяються на три головні підгрупи: робота на висоті, стрибки та падіння з різної висоти, стрибки та падіння з різних видів 
транспорту в русі); кінні; піротехнічні; сценічний рух, або рукопашний бій чи бій зі зброєю; трюки на та під водою автомобільні, мотоциклетні та інші трюки пов'язані з за діянням техніки (для виконання даної категорії трюків зазвичай запрошують професійних авто-, мотогонщиків, пілотів та парашутистів, тоді як усі інші категорії виконують каскадери-універсали) [6, 75]. На сучасному етапі каскадерське мистецтво в Україні представлено кількома поколіннями постановників та виконавців трюків, які розпочали професійну діяльність у кіноіндустрії за радянських часів (А. Грошевой, В. Строкань, О. Юрчишин, О. Данильченко, І. Мрихін, В. Мисливий, О. Філатов та ін.) та після проголошення незалежності України (Є. Круглов, I. Юрчишин, С. Шляхтюк, С. Ярмоленко) У більшості це професійно підготовлені, універсальні акторикаскадери, які володіють різноманітними видами трюків, а деякі $є$ винахідниками та авторами інноваційних трюків.

Вагомий внесок у розвиток вітчизняного каскадерського мистецтва здійснюють державні та громадські професійні організації: Міжнародна асоціація професійних каскадерів "Україна" (1997 р., засновник А. Грошевой); Ліга каскадерів України (1997 р. засновник О. Філатов); Об’єднана Ліга професійних кінних каскадерів (засновник та керівник О. Юрчишин).

Наприклад, Ліга каскадерів України, у складі якої діють івентагенство "Stunt-шоу”, підрозділ автомототрюків, кінно-трюкові театри “Українські козаки”, “Скіф”, кінний театр “Кентавр”, театри “Одіссей”, "Каскадер", а також майстерня 3 виготовлення декорацій, зброї та обладунків [4], з 2010 р. проводить Міжнародний фестиваль каскадерів "Київська Русь", з метою створення соціокультурного простору для діалогу між представниками кіно- та шоу-індустрії (продюсерів, режисерів, каскадерів, акторів та благодійників). Окрім демонстрацій професійних навичок та конкурсу на кращий кінний трюк, важливою частиною програми фестивалю є проведення майстер-класів зі сценічного руху (робота з холодною зброєю, поєдинки, бійки, єдиноборства), висотно-акробатичних та висотних трюків із застосуванням спеціального спорядження; мотоциклетних та автомобільних трюків (підготовка ігрової техніки до трюкових зйомок, екстремальна їзда по пересіченій місцевості та аварійні ситуації); кінних трюків (підготовка коней до трюкових та батальних сцен, джигітування, трюки з гужовим транспортом); підготовка та виконання трюків із застосуванням піротехнічних засобів; техніки безпеки під час трюкових зйомок; спеціальні ефекти у трюкових зйомках, та ін., участь у яких беруть не лише професійні каскадери, а й студенти акторських факультетів, які мають відповідну підготовку [1].

На думку О. Філатова проведення подібних заходів посприяє подальшому розвитку професії, вдосконаленню виконавської майстерності, зміцненню та розвитку матеріально-технічної бази для забезпечення трюкових зйомок, розробці нових засобів та способів страхування каскадерів та акторів на знімальному майданчику [1].

Нині в Україні - одній з небагатьох країні в світі (станом на 2014 р.), в якій професія каскадера затверджена на державному рівні, працює приблизно 100 каскадерів, $з$ них 15-ть жінок. Варто зазначити, що специфікою вітчизняних каскадерів $\epsilon$ універсальність, оскільки на відміну від американських та західноєвропейських вузькоспеціалізованих каскадерів, українські підготовлені до виконання будь-якого трюку.

Мінімально каскадерська група має складатися з чотирьох осіб - постановника трюків, виконавця та страхувальників (не менш досвідчених аніж виконавець каскадерів), завданням яких є забезпечення безпеки виконавця у випадку небезпеки (наприклад, витягнути з автомобіля, з-під коня, з-під води, вчасно загасити вогонь та ін.).

Надзвичайно популярною українською каскадерською групою на сучасному етапі є "Stuntalot crew", яку заснували та очолили досвідчені каскадери Д. Рудий та П. Авілов - постановники бойових сцен у голлівудському фільмі “300 спартанців 2” (режисер Н. Мурро, 2014 р.), одних з найкасовіших вітчизняних фільмах: "Межа" (режисер П. Беб’як, 2017 р.), “Сторожова застава” (режисер Ю. Ковальов, 2017 р.), "Кіборги” (режисер А. Сеїтаблаєв, 2018 р.), “Легенда Карпат” (режисер С. Скобун, 2018 р.), “Захар Беркут” (режисер А. Сеїтаблаєв, 2019 р.) та ін.

Аналізуючи специфіку каскадерського мистецтва в контексті сучасного вітчизняного кіновиробництва, вважаємо за доцільне більш детально дослідити процес створення та зйомок трюкових сцен. Постановка трюкових сцен відбувається у співпраці режисера фільму та керівника каскадерів (посаду за радянських часів називали тренер-постановник), специфіка діяльності яких зумовлюється специфікою кіновиробництва. Зазвичай у сценарії фільму немає ретельної розробки сцени, а вказується лише що має відбуватися і чим повинна закінчуватися сцена. Безпосередньо дія розробляється у найменших подробицях саме постановником трюків, репетирується з акторами та дублерами, а потім демонструється режисеру. Складність полягає не лише в тому, що сцену необхідно вигадати, а й в тому, що трюковий епізод має органічно поєднуватися 3 загальним орнаментом картини, не порушуючи темпоритму фільму, а також максимально сприяти втіленню творчого бачення режисера. Окрім того, рухи та пластика каскадера- 
дублера має бути максимально наближеною до пластики актора, яку він використовує для створення образу свого персонажу.

Специфіка діяльності постановника трюків передбачає урахування багатьох аспектів, оскільки трюк - це мікросюжет, який повинен повністю відповідати не лише загальній ідеї фільму, але й його тональності, ритму та ін.

Серед найважливіших назвемо такі:

- розробка трюку або трюкової сцени (серія трюків пов'язаних між собою загальною сюжетною лінією, що слідують один за одним; як і кожен окремий трюк, серія має зав'язку, кульмінацію та розв'язку драматургічний лад, що виражається засобами моторики. - Авт.) відповідно до художнього бачення режисера, оскільки будь-який кінотрюк - це певний образ, частина єдиного художнього твору. Щоб осмислити загальну спрямованість трюку або трюкової сцени, а також зрозуміти світовідчуття режисера, постановники трюків мають проводити величезну попередню роботу - переглянути відзнятий матеріал, близько спілкуватися з акторами, щоб визначити їх індивідуальність, темперамент та рухові можливості;

- трюки повинні відповідати жанру кінопродукції (наприклад, в комедії - викликати у глядача сміх, а в драмі - співчуття);

- оскільки трюки у багатьох випадках є характеристикою персонажів, доречно, наприклад, під час постановки рукопашного бою, використовувати для створення позитивного образу героя відмінні прийоми, ніж для негативного;

- головний етап роботи - підготовчий, під час якого чітко формуються уявлення про трюк, його специфіку, проводяться тести з каскадерами, знімаються відеоролики, щоб режисер вніс, при необхідності, деякі уточнення, проводиться навчання акторів (за умови якщо трюк не виконує дублер), а також прораховуються будь-які форс-мажорні випадки на знімальному майданчику, 3 метою забезпечення безпечного виконання трюку.

До початку трюкових зйомок ретельно готується кожний епізод та кадр - визначається місце та напрямок руху акторів, проводяться репетиції дій зі зброєю, готуються місця для вибухів, падіння та ін. Відпрацьовується кожен рух актора, каскадера або дублера.

Каскадер (людина, яка пройшла спеціальну підготовку і виконує трюкові дії на знімальному майданчику) може виступати дублером актора, проте не завжди дублер (професійний спортсмен або спеціаліст-аматор у певній галузі спорту, наприклад, авто-, мото- або велоспорті, кінному спорті, альпінізмі, плаванні, більярді та ін., або нерідко й в будь-якій іншій галузі, наприклад, дресируванні хижих тварин, фокусах, грі на музичних інструментах, образотворчому або декоративно-прикладому мистецтві, танцях та iн., який підміняє актора, якщо в цьому $є$ необхідність) $є$ каскадером. Так, наприклад, для зйомок рукопашного бою, схватки, бійки, падінь - складних але видовищних епізодів сценарію - за радянських часі зазвичай запрошувалися спортсмени-самбісти, оскільки добре підготовлений самбіст володіє різноманітними видами холодної та вогнепальної зброї, і може не лише захищатися від нападу, але й контратакувати навіть кількох супротивників. Окрім того саме самбісти вивчають та постійно вдосконалюють різноманітні способи безпечних падінь.

Постановка батальних епізодів має власну специфіку - прийоми бою зі зброєю мають відповідати історичному часу, географічному розташуванню, соціальній приналежності персонажів та багатьом іншим аспектам, означених у кожному конкретному кіносценарії. Зазвичай режисеру набагато легше підібрати каскадерів для виконання сучасних батальних сцен, аніж історичних, проте навіть вони мають відповідати загальній ідеї кінострічки, а головне - образам головних чи другорядних персонажів та масовки. Так, наприклад, при відтворенні рукопашного бою військових, охоронців або поліцейських, не можна використовувати прийоми, які застосовують бійці загонів особливого призначення. Це ж стосується і постановок побутових бійок, боксерських турнірів, поєдинків з бойових мистецтв.

При зйомках історичних фільмів складність постановки батальних сцен та епізодів набагато більша і передбачає ретельне вивчення архівних матеріалів, зброї та прийомів бою, специфіки костюмів та етнографічних аспектів життя та побуту людей конкретної історичної епохи, з метою відтворення на екрані достовірної обстановки. Після цього постановник трюків розробляє сцени, спочатку схематично, а потім в декораціях, костюмах та зі зброєю відпрацьовуються удари, захист та падіння, обираючи, за умови необхідності дублювання, серед каскадерів власної групи кращих у певних видах трюків, наприклад, фехтуванні на рапірах, на мечах, рукопашному бою, верховій їзді та ін. Якщо актор володіє певними навичками, необхідними для самостійного виконання трюків, або трюки не вирізняються надзвичайною складністю виконання і є можливість, за згодою актора, досить в короткий період часу його навчити необхідним прийомам, постановник відпрацьовує сцену з ними. В обох випадках, після репетицій сцена демонструється режисеру, і за умови позитивної оцінки, готується до зйомки. 
Наукова новизна. Досліджено діяльність професійних організацій каскадерів України та провідних каскадерських груп (Міжнародної асоціації професійних каскадерів “Україна”, Ліги каскадерів України, Об'єднаної Ліги професійних кінних каскадерів, "Stuntalot crew") початку XXI ст.; здійснено мистецтвознавчий аналіз постановки та виконання трюків у контексті розвитку сучасної вітчизняної кіноіндустрії; проаналізовано окремі аспекти роботи постановника трюкових сцен у фільмі, згідно специфіки жанру та ідейного задуму режисера.

Висновки. Специфіка каскадерської діяльності в кіноіндустрії України зумовила доцільність використання започаткованого в радянському кінематографі другої половини XX ст. групового підходу провідні каскадери та постановники трюків створюють власні групи, з якими працюють на знімальному майданчику.

Еволюція кінознімальної апаратури та залучення у кіноіндустрію комп’ютерної графіки на сучасному етапі значно сприяє каскадерській діяльності. Наприклад, завдяки можливості стерти страхувальні троси під час пост-продакшн (робота з відеорядом після завершення зйомок), каскадери можуть вільно використовувати страхування; замість використання традиційних для радянських часів спеціальних ножів, в які вставлялися капсули з кров'ю, що розбризкувалася при нанесенні удару, нині наліплюються або малюються поранення, безпосередньо по яким наносять удари (на етапі пост-продакшн поранення до моменту ударів затираються). Проте, багато аспектів ії специфіки залишилися незмінними. Не дивлячись на можливість створення найрізноманітніших спеціальних ефектів, каскадерське мистецтво лишається незамінною і невід’ємною частиною кіноіндустрії.

\section{Jimepamypa}

1. Андриенко В. Кинобратство. URL : www.viktor-andrienko.com/news/2458 (дата звернення : 12.09.2019). C. $903-908$.

2. Маслов-Лисичкин А .О. Истоки и становление каскадерського искусства. Молодой ученый. 2015. № 7 (87).

3. Маслов-Лисичкін А. О. Каскадерські школи в радянському кінематографі. Мистецька освіта в культурному просторі України XXI століття: Зб. матеріалів Міжн. наук.-творч. конф., Київ, Одеса, 28-30 квітня 2015 р. Київ : НАКККіM, 2015. С. 288-291.

4. Працюк О. М. Каскадерів України Ліга. Енциклопедія сучасної Украйни. 2012. URL : http://esu.com.ua/search articles.php?id=10247 (дата звернення : 12.09.2019).

5. Семака Л. Анатолій ГРОШЕВОЙ: 'Україна - єдина країна у світі, де професія каскадера затверджена на державному рівні”. 2014. 12.07.Урядовий кур'єр. URL : https://ukurier.gov.ua/uk/articles/ anatolij-groshevoj-ukrayina-yedinakrayina-u-sviti (дата звернення : 12.09.2019).

6. Сысоев Н. Настольная книга каскадера. Санкт-Петербург: Мифрил, 1998. 288 с.

7. Теракопян М. Л. Развитие кинообразности под влиянием компьютерныхх технологий : автореферат дис. канд. искусствоведения : 17.00.03 / Всероссийский государственный университет кинематографии имени С. А. Герасимова. Москва, 2008. 20 с.

\section{References}

1. Andrienko, V. Film Brotherhood. Available at : www.viktor-andrienko.com/news/2458 [in Russian]. Russian].

2. Maslov-Lisichkin, A. O. (2015). The origins and formation of stunt art. Young scientist, no. 7 (87), pp. 903-908. [in

3. Maslov-Lisichkin, A. O. (2015). Stunt schools in Soviet cinema. Art Education in the Cultural Space of Ukraine in the 21 st Century: Coll. materials International scientific-creative. Conf., Kiev, Odessa, April 28-30, 2015. Kyiv: NAKKKiM, pp. 288-291. [in Ukrainian].

4. Pratsyk, O. M. (2012). Stuntmen of Ukraine League. Encyclopedia of modern Ukraine. Available at : http://esu.com.ua/search_articles.php?id=10247 [in Ukrainian].

5. Semaka, L. (2014). Anatoliy GROSEVOY: "Ukraine is the only country in the world where the stuntman's profession is approved at the state level". Government Courier. Available at : https://ukurier.gov.ua/en/articles/ anatolijgroshevoj-ukrayina-yedina-krayina-u-sviti [in Ukrainian].

6. Sysoev, N. (1998). Handbook stuntman. St. Petersburg: Mithril. [in Russian].

7. Terakopyan, M. L. (2008). The development of cinematography under the influence of computer technology. Abstract of Ph.D. dissertation. Moscow : All-Russian State University of Cinematography named after S. A. Gerasimov. [in Russian].

Стаття надійшла до редакції 19.09.2019 Прийнято до публікаиії 28.10.2019 